\title{
The Intellectual Capital Model Towards Optimizing the Performance of Informal Sector Entrepreneurs in The City of Medan
}

\author{
La Ane \\ Doctoral Student of Education Technology \\ Graduate School of Medan State University \\ Medan, Indonesia \\ E-mail : laane_gu@ymail.com \\ La Hanu \\ Faculty of Economics State University of Medan \\ Medan, Indonesia \\ Sahat Siagian \\ Educational Technology- Postgraduate Program, State University of Medan \\ Medan, Indonesia \\ Abdul Hamid K \\ Educational Technology- Postgraduate Program, State University of Medan \\ Medan, Indonesia
}

\begin{abstract}
This study aims to formulate a suitable model in developing the capacity of entrepreneurs in informal sector at Medan City. More specifically, the research conducted through several steps including 1) to identify the condition of human capital, social capital and organizational capital within informal sector entrepreneurs in Medan City as well as to determine their entrepreneurship orientation; 2) to propose the best fit model that enabling the entrepreneurs of informal sector in Medan city to optimize their performance by considering the condition of their current intellectual capital and entrepreneurship orientation. The research was carried out using ex-post facto approach. Data were collected using questionnaires. The sample of the research consists of 100 entrepreneurs involving in the informal sector in Medan which was categorized based on the location factor and the
\end{abstract}

\section{INTRODUCTION}

\section{Background}

The informal sector plays an important role in providing employment opportunities for the people of Indonesia. The nature of the work that is easily accessible without a specific qualification or easy to entry make this sector the mainstay for many workers towork. North Sumatra Provincial Bureau of Statistics data, the results Sakernas August 2014 and February 2015 show that the proportion of workers who work in the informal sector reached 59.90 percent of the total type of business they are being managed. Data analysis in this research uses descriptive analysis and hypothesis test using $t$ test. The result of the t test shows that $t$-count for Hypothesis 1,2 and 3 are $2.18 ; 1.99 ; 2.43$ respectively and are significant with $<0.05$. This data analysis result underlines that the human capital, social capital and organizational capital influence the entrepreneurship orientation of entrepreneurs of the informal sector in Medan city significantly. It can be concluded that the low condition of each human capital, social capital and organizational capital of informal sector actors have the potential risk of decreasing their orientation of entrepreneurship leading to their low entrepreneurship performance.

Keywords: Human Capital, Social Capital, Organizational Capital, Entrepreneurship Orientation, Informal Sector

working population of 6.17 people. Informal sector employment is widely available in urban areas because of the variety of work that allows for the creation of employment in the informal sector. This has become one of the attractions for residents in rural areas to move to urban areas, leaving increasingly dense urban population and most of them are informal sector workers. But look at the nature and conditions of employment in the informal sector, then the sector can be classified to businesses that marginal and face several challenges in its development. Once discovered 
many factors that cause the increase in the number of workers in the informal sector are: (1) the tendency of increasing the role of informal sector in employment and able to provide revenue for the culprit; (2) The tendency of the informal sector rigidities in labor receive from a variety of different backgrounds (gender, age, education, skills / expertise and capital); and (3) The opportunities for developing the urban informal sector / productive as the formal sector.

Central Statistics Agency (BPS) North Sumetara in February 2015 recorded a total of 2.48 million people or 40.10 percent are employed in formal activities (seeking assisted permanent workers and laborers / employees) and as many as 3.70 million people or 59.90 percent work in informal activities. Those who enter the informal sector enterprises, initially intended to seek employment and generate income. Most of those involved are those of migrants from poor, less educated and less skilled. Indeed Informal sector as a term often used to indicate the activity of perekonomian small scale, has a close link with the problem of urban poverty. Ironically it along with the rise of poverty alleviation programs implemented last few years, economic activities of the informal sector as a source of livelihood of the urban poor majority no-kan adequately accommodated.Activity into the informal sector in the city is more aimed at finding employment and income of the gain. Those involved in the informal sector are generally poor, low-educated, unskilled and mostly newcomers. Many of the problems faced by the workers of the informal sector, the general problems faced by the workers of the informal sector can be divided into two issues of external and internal problems. External issues related more to the number of competitors similar business conditions, facilities and inadequate economic infrastructure, lack of adequate training, limited access to credit. Internal problems associated with weakness in the capital, organization and management, the limitations of commodities sold, the lack of cooperation and lack of education and the quality of human resources.

It is known that the number of informal sector workers in Medan annually increasing, but some of the activities of informal sector workers to have access to resources like the formal sector also remains limited. In the case of the informal sector is one of the capital in urban integral transformation of the urban economic system. Availability of formal sector employment is not the only indicator of job availability. The existence of the informal sector too is a form of full employment. Quite a lot of studies in developing countries which demonstrates that not all informal sector actors interested in moving to the formal sector. For them to develop entrepreneurship is more attractive than a worker in the formal sector. This indicates that the resource constraints that exist in the informal sector workers may not necessarily be the main obstacle for the development of its business, although there are still many informal workers, and there are not successfully run and expand their businesses. To be a successful informal sector workers requires a lot of skill and a strong social network.

On the other hand, the informal sector is not well ordered. Difficulties in data collection number of informal entrepreneurs often make the government implement policies that are unfavorable to informal entrepreneurs. The government only recognizes their existence, but it does not provide the protection that should be done. The emergence of informal markets is then accused by the government as the most unmanageable. Restrictions expansion by informal sector entrepreneurs can make their economic situation is not well developed. The informal sector is also considered to be a structural problem, present because of their poverty. Whereas the governments themselves do not create adequate facilities and infrastructure to meet the needs of this informal market. And efforts to towards improvement, the realignment of the informal economy for the better very minimal done when sector informally need to be empowered to carry out profound and fundamental changes. Assistance in total involving socio-economic conditions so that from the beginning of the informal sector beset up to be entrepreneurs are resilient. We need to think how to foster and enhance the human resource capability actors of the informal sector through training, courses or internships, so they are better able to expand its business into a larger business, so that one day may allow for the switch in as businessmen formal or at least they can be selfemployed successfully and earn revenue as informal sector workers are higher than ever before.

Based on such exposure is known that one of the reasons for poor performance of the informal sector was lack of resources available. Lack of resources within the informal sector leads to lower or control the development of science and technology which is owned intellectual capital. In fact, in the era of free trade and globalization of the world economy, science and technology together with HR are the two dominant factors in determining the level of competitiveness. The informal sector that can survive both in the domestic and global markets are efficient informal sector. Informal sector actors (human resources) needs to have sufficient knowledge and skills in order to compete in 
the global market. The informal sector needs to be managed properly like the formal sector (entity). Management encompasses the aspects of cooperation with partner networks (social capital) which includes collaboration with partners, suppliers, owners of funds (banking), and the government. In addition to the informal sector business management (organizational capital) needs to be organized professionally oriented entrepreneurship like the formal sector (SMEs) to ensure business continuity and viability as a business entity.

To answer these problems, the informal sector need to use management strategy of intellectual capital that is done through: 1) Improve the human resources of SMEs on the importance of science and technology, 2) Improve the access and cooperation network, 3) Improve the quality and standard of penngelolaan effort, 3 ) Improve the government's role is mainly to deliver them to compete with other businesses.

\section{Problem Formulation}

Based on the foregoing, the problem in this research is formulated as follows:

1. How does the human capital informal sector operators to the orientation of all wirausahaan?

2. How does the social capital of the informal sector players against entrepreneurship orientation

3 How does organizational capital on entrepreneurial orientation?

3. How to model the informal sector guidance to do with mempertimbang-kan condition of intellectual capital and entrepreneurial orientation exist in the informal sector actors?

\section{Specific Objective}

This study was conducted to find the modelbased development of the informal sector entrepreneurship orientation. Model-based development of the informal sector entrepreneurship orientation is expected to be a form of strategies to improve the ability of informal sector workers.

Operationally, this study aims to:

1. Identify the condition of humancapital, social capital and organizational capital informal sector in Medan and its influence on entrepreneurial orientation.

2. Formulating the influence of human capital informal sector operators to the orientation of all wirausahaan.

3. Formulating the influence of social capital informal sector operators to the orientation of allwirausahaan
4. influenceformulateorganizationalcapital informal sector operators to the orientation of all wirausahaannya.

5. Formulate a model of development of the informal sector should be done by considering the condition of intellectual capital and entrepreneurial orientation exist in the informal sector players.

\section{METHOD}

This study usesapproachex post facto to assessing the linkages between humancapital, social capital, and organizational capital on entrepreneurial orientation. This research was conducted in the informal sector actors in Medan. The sampling technique using proportional random sampling by taking into account the area or the location of the informal sector and the factors of business managed by informal sector workers. The number of samples in this study as many as 100. The data in this study were collected using questionnaires. The data collection is done directly to ask the respondents to fill out the questionnaire. Before the questionnaire distributed to respondents, will first test the validity and reliability test on the instrument. A valid and reliable instrument that will be used to collect research data.

Data analysis in this research is done using simple regression analysis and hypothesis testing using t test, with the first meeting the requirements analysis: normality test, homogeneity test, and test linierlitas. Test for normality using the Kolmogorov-Smirnov technique, homogeneity test using levene test and linearity test using test $\mathrm{F}$ (linierity).In the diagram the relationship between variables in this study as follows:

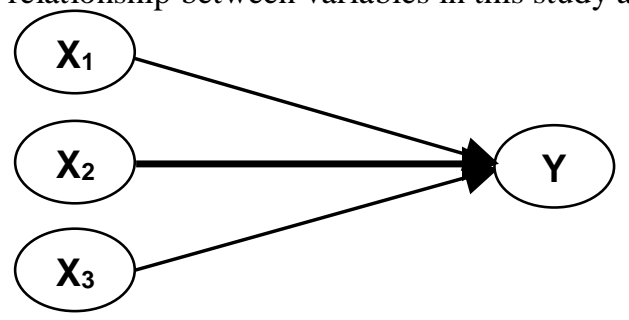

Figure 1. Conceptual Framework

Description:

1. X 1: Human Capital

2. X 2: Social Capital

3. X 3: Organizational Capital

4. Y : Orientation Entrepreneurship 


\section{Results and Discussion}

Based on descriptive analysis known that the tendency of respondents to all variables there are in the medium category, respectively, are as follows: Human Capital by 72 or $72 \%$, Social Capital by 67 or $67 \%$, Organizational Capitalfor 63 or $63 \%$ and Entrepreneurship orientation by 68 or $68 \%$.

Based on the inferential statistical analysis to test the hypothesis of the study found that the three hypotheses tested by the value of $t$ is greater than $t$ table at a significance level of $\alpha=0.05$. Model research results can he seen in the figure below:

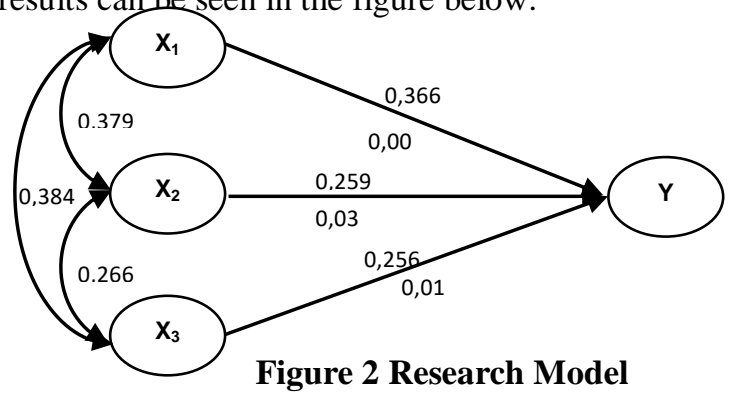

The followingdescribed the results of data analysis to test the hypothesis, which shows the influence of each variaabel free: Human Capital,Social Capital and Organizational Capital and bound variables: Orientation Entrepreneurship.

1. The influence of human capital on the orientation of the entrepreneur informal sector operators

results showed t count between human capital to the entrepreneurial orientation $\mathrm{t}_{\mathrm{t}}=3.70>\mathrm{t}_{\mathrm{table}}=1.98$, with a significance level of 0.000 means significant. Thus proven through research that the human capital effect on entrepreneurial orientation.

The results are consistent with the opinion of $\mathrm{Hsu}$ and Fang (2009) ${ }^{(1)}$ that the business workers who have good ability and experience high will help organizations to create knowledge and be able to adopt information from the outside to be used in the organization, especially in improving organizational learning and innovation. Organizational learning and innovation is a form of operationalization of entrepreneurial orientation.

The implications of these results that the implementation of intellectual capital which in this context is the human capital that is operationally measured by the ability, experience, expertise and ability to work together in a team will greatly assist the development of the business organization. With an established human capital will facilitate the strategy of utilizing an important role in increasingkan human resources and organization to become an entrepreneur. human capital An establishedwould show a tendency to behave in a more clear and focused. The potential that exists in human capital will facilitate the achievement of a high entrepreneurial performance as a clear entrepreneurial orientation. Human capital represented by penddikan high level, the experience can increase the selection and in-app entrepreneurial orientation.

2. The influence of social capital on the informal sector players entrepreneurial orientation

results showed t count between human capital to the entrepreneurial orientation $\mathrm{t}_{\mathrm{t}}=2.19>\mathrm{t}_{\text {table }}=1.98$, with a significance level of 0.031 means significant. Based on the value ofstatistically significant social capital positive effect on entrepreneurial orientation.

The results are consistent with the opinion of Huang and Wang (2011) ${ }^{[2]}$ and Huang et al. (2010) which states that social capital be a good basis for the development of entrepreneurial activity facilitates the achievement of business competitiveness. Social capital plays a key role in entrepreneurial activity due to the socio-economic process depends on: First, entrepreneurship is the result of social and environmental products that both entrepreneurship is a social activity whose existence will be strongly influenced by their social relationships and connections. Social relationships bias in the form of networking, collaboration, connectivity etc and this aspect will affect the entrepreneurial orientation of a person.

The implications of these results that a person in a social group that has social capital a morewill have more potential to recognize and take advantage of business opportunities. When aspects of social solid and strongcapital,it will help to build confidence between them which in turn will be able to bring innovative ideas, proactive, willing to take risks and take advantage of opportunities and taking part in entrepreneurship. In addition, a shared vision and purpose among members of the organization showed the cognitive aspects of social entrepreneurship, through the creation of value 
leads to integrity and sense of responsibility and ultimately conducive to entrepreneurial orientation.

3. The influence of organizational capital informal sector operators to the orientation kewirausahaannya

results showed $\mathrm{t}$ count between organizational capital on entrepreneurial orientation $\mathrm{t}_{\mathrm{t}}=2.59>\mathrm{t}_{\text {table }}=$ 1.98 , with a significance level of 0.011 means significant. Based on these statistically values, organizational capital positive effect on entrepreneurial orientation.

The results are consistent with the opinionPiirala ${ }^{[3]}$ (2012) which states that entrepreneurial orientation is strongly influenced by cultural factors. The ability of entrepreneurshipcommunityin a country depends on a very special combination of cultural factors. The culture when implemented in the organization will be the main source for innovation. In addition, the results of this study are also in line with the opinion of Hofstede (2010) which states that there are several dimensions of culture that can influence the entrepreneurial orientation of which is individualism, masculinity, uncertainity avoidance, power distance and longvs. short-term orientation. Kultur / culture is considered ideal and support the high entrepreneurial orientation according to Hofstede's theory if the combination is as follows: The level of entrepreneurial orientation in research both at home and abroad, convicted affect performance.

The implications of these results thatentrepreneurial orientation is strongly influenced by the culture that exists in the business organization. Operationalization of the culture is the attitudes, values and behaviors that everything will be the basis for the business in this case is the informal sector to understand more about the management of the business carried on. This means that some will bridge the cultural dimensions of informal sector operators in understanding the management philosophy of business management. The higher the business management philosophy that is understood by the actors of the informal sector, the higher-rausahaannyakewi orientation.

\section{CONCLUSION}

Based on the analysis and discussion of the results obtained the following conclusions:

1. Effect of human capital to the entrepreneurial orientation. Based on the results of data analysis known that the value of $f_{t}=3.70>t_{\text {table }}=1.98$, with a significance level of 0.000 means significant. Based on the value ofstatistically significant human capital positive effect on entrepreneurial orientation. Thus, the hypothesis states that the lower human capital informal sector players the lower the entrepreneurial orientation is acceptable.

2. The influence of social capital on entrepreneurial orientation. Based on the results of data analysis known that the value of $\mathrm{t}_{\mathrm{t}}=$ $2.19>\mathrm{t}_{\text {table }}=1.98$, with a significance level of 0.031 means significant. Based on the value ofstatistically significant social capital positive effect on entrepreneurial orientation. Thus, the hypothesis states that the lower social capital informal sector players the lower the entrepreneurial orientation is acceptable.

3. The influence of organizational capital on entrepreneurial orientation. Based on the results of data analysis known that the value of $\mathrm{t}_{\mathrm{t}}=$ $2.59>\mathrm{t}_{\text {table }}=1.98$, with a significance level of 0.011 means significant. Based on these statistically values,organizational capital positive effect on entrepreneurial orientation. Thus, the hypothesis states that the lower organizational capital informal sector players the lower the entrepreneurial orientation is acceptable.

Based on the conclusions of the above, it can be conveyed some suggestions as follows:

1. Human capital is the driving force of entrepreneurship,thereforehuman

capitalproxiedin the form of knowledge, expertise, skills, competencies and experience becomes the basis for moving the informal sector players entrepreneurial behavior. The high knowledge, expertise, skills, competence and experience possessed by the informal sector operators will improve their ability to achieve competitive advantage and competitiveness. Given this it needs the attention of berbaga parties, universities, the government in this case the Department of Cooperatives and SMEs, the Department of Trade and Industry, Department of Tourism and Culture as well as state and private to be able to provide guidance for the actors of the informal sector in order to improve the knowledge, skills, skills, competencies and experience through education and training. 
2. Social Capital in the form of networking, cooperation and relational relationship with all the players in the informal sector as well as with the various parties are well constructed will increase the confidence of the informal sector players. This confidence will motivate and capital informal sector players to be proactive in doing business innovation. Therefore need mentoring program for informal sector groups to establish the association between the informal

\section{REFRENCES}

[1] Hsu, Y-H, \& Fang, W, 'Intellectual capital and new product development performance: the mediating role of organizational learning capability', Technological Forecasting \&Social Change, Vol. 76, 2009, pp.664-677

[2] Lee D Y and Tsang E W K, The Effect of Entrepreneurial Personality, Background and Network Activities on Venture Growth, Journal of Management Studies38-4, 2011, pp 583602.

[3] Piirala P, The Impact of Entrepreneurial Orientation on Firm Performance: A Comparative Study of Finnish and German SMEs. SME Business Management, Master Thesis. Aalto University. Runebergsgation, Finland, 2012

[4] Sveiby, K.E. The New Organizational Wealth: Managing and Measuring Knowledge-based Assets. San Francisco: BarrettKohler Publishers, 2007. sector and memfasillitasi initiated the necessary programs to improve their entrepreneurial orienntasi.

3. The need forassistance program organizational capital in the form of structuring the organization and management of the informal sector so that the business developed so orderly and neat-managed business unit will evolve towards the formal sector.

[5] Stewart Jr W H, Carland J C, Carland J.W, Watson W E and Sweo R, Entrepreneurial Dispositions and Goal Orientations: A Compative Exploration of United States and Russian Entrepreneurs, Journal of Small Business Management41-1, 2008, pp. 27-46

[6] Mayo, A. The Role of Employee Development in The Growth of Intellectual Capital.Personnel Revie. 29. 2010. Issue 4

[7] Tohar, Ali. Profi ldan Strategi Pengembangan Sektor Informal di Kota Medan (StudiKasusPedagangMakanandanMinuman). TesisUniversitas Sumatera Utara, 2009.

[8] Hisrich R D, Peters M.P., Shepherd D.A., 2006 Entrepreneurship 6th ed. McGraw-Hill Boston. 